\title{
Debates
}

\section{Classes of Labour in India: A Review Essay}

\author{
Jan Breman, University of Amsterdam, The Netherlands
}

[Editor's note: This review essay is based on the following publication: Jonathan Parry (in collaboration with Ajay T.G.) (2019) Classes of Labour: Work and Life in a Central Indian Steel Town. New Delhi: Social Science Press. ${ }^{1}$ ISBN 9789383166343. 732 pages. ₹1850 hardcover.]

\section{ABSTRACT}

From the very beginning of my writing on the regime of informality I have rejected the notion of a dichotomy between formal and informal labour relations. The fracturing solidifies a differentiated absorption in the labour process - own-account workers versus waged labourers, regular against casual employment, replacement of sedentary engagement in paid work by footloose mobility and all of this culminating in divergent patterns of livelihood and lifestyles. It is along these lines that I have split up "informality" class-wise, following up on the contention that rather than juxtaposing the working class as an amalgamated lot, there are indeed diverse classes of labour with distinct identities. The way in which differentiation has come about cannot only be comprehended in terms of social class-based alignments but also finds expression in an axis of steep inequality. It is a ranked order taking the shape of a class-caste nexus and makes clear how corresponding trajectories of accumulation and dispossession operate in tandem. The backdrop to this essay is the process of informalisation pushed by the stakeholders of globalised capitalism from the early 1970s onwards. The shift away from the regime of formality which used to be enjoyed by a minor segment of India's mega-workforce has in many instances ended their privileged employment, legal protection and social security, tearing up the domains in which labour moves around.

Jonathan Parry's Classes of Labour: Work and Life in a Central Indian Steel Town is a monumental synthesis of the anthropological research which the author has carried out in the central Indian steel town of Bhilai. His rounds of fieldwork have added up to thirty-four months spread over two decades, but the chronicle published is an ongoing story starting before his presence on the site. Moreover, in Parry's absence his associate Ajay T.G., firmly embedded on the spot, continued to report on what went on in and around the selected locales of investigation. The writing up is in the nature of a case study, superbly framed however in the wider context of the changing size, shape and plight of India's workforce since independence. The book's ambit is similar to what I have

\footnotetext{
${ }^{1}$ Social Science Press published the South Asia Edition in 2019. The next year, Routledge published an international addition. Details for the Routledge paperback edition are: ISBN 9780367510329, 732 pages, $£ 29.59$.
} 
focused on for a major part of my academic work - to understand in India's transition from a peasant to a post-peasant economic, social and political order the vicissitudes of people dependent for livelihood on the sale of their labour power. While our findings have much in common, we hold different views on how to validate and come to terms with them. My suggestion is that this contrast in perception and perspective stems from our opposite points of entry doing fieldwork in short, a top-down versus a bottom-up approach.

Before elaborating on the implied divergence of how to make sense of the multi-layered landscape of labour, I would like to express my appreciation for the magnificent account Jonathan Parry has produced on the postcolonial fate of India's working classes. In the first place, I want to highlight the impressively detailed ethnographic narrative which brings us, without any statistical tabulation or graphs at all, close to the facts, fads and fancies of the people portrayed. Gaining access to the steel mill and its shopfloor enabled the investigators to collect a comprehensive set of data on the labour process and its stakeholders as well as documenting when, why and how major changes came about in the strength and composition of the plant's workforce over time. Their findings are an important contribution to the sociology and history of industrial labour in the country. But the research conducted did not remain restricted to participant observation at the site of work; it was extended to the township which became the abode of Bhilai's employees and their households. Zooming in on this residential zone resulted not only in information on the housing facility made available but also allowed for probing into family life and gender relations, childhood and growing up, the role of kinship and getting married, the stages passed through from youth to old age. Insight into the phasing of livelihood in upward or downward mobility was gained by tracing informants in their intergenerational reproduction. All these telling features could be put on record by backing up anthropological contemporaneity with a sense of historicity in the modus operandi. Still, this rich inventory is not more than half of the tableau presented.

The Bhilai enterprise was one of the first Public Sector Undertakings set up to pave the way out of poverty and backwardness. Stuck in stagnation under British domination, the transformation designed and executed by India's state-makers was supposed to follow the evolutionary path of development that took place in the North Atlantic Basin from the nineteenth century onwards. These European-American nations had in dynamic growth and modernity restructured themselves from agrarian-rural to industrial-urban economies and societies, a turnaround which resulted in progress and welfare all around. The steel mill was established as one of the temples of India's state-sponsored industrial future. Constructed in the mid-1950s, the plant started to operate with a workforce brought in from many parts of the subcontinent, a social mix "in which difference of caste, regional ethnicity and religion were, if not dissolved, at least dulled" (p. 26). Settlement of these outsiders in the simultaneously built middle-class housing colonies toned down their separated identities. Joint habitation in Company Town thus enhanced the idea of a melting pot.

Decent work in the plant and comfortable life in the township testified to emancipatory assertion. Crucial for this welcome prospect to materialise was the preferential treatment given to this vanguard of the awaited welfare state: a labour contract stipulating fair conditions of work, protection against adversity (failing health, old age or unwarranted dismissal), supplemented by social perks also shared by members of the workers' households. Expanding on a shallow body of labour rights introduced under colonial rule, the postcolonial state built up a public domain regulating in minute detail employment of its own personnel (officials, police, army) and extending this legislation to employees in public transport, communication, sanitation, health and education as well as to the industrial workforce in state-owned and managed modern enterprises. Job security and wages paid in this public sector of the economy would gradually spread to benefit the nation's workforce at large. It meant that, for the time being, the majority of unregulated labour remained 
dependent for livelihood on the basis of discrete and individualised arrangements of unspecified duration made between employer and employee. The imposition of limited legal leverage marked the watershed divide between what became labelled as formal and informal employment.

Parry located his first ten months' spell of fieldwork in 1993-1994 mainly in Bhilai's plant and Company Town, observing from close by the stable work and life rhythm of this labouring elite. But he was of course astutely aware of the sharply contrasting modes of informal engagement in the vast terrain beyond this enclave. Already then, but more so in subsequent rounds, he investigated a variety of these informal modes: workers in private sector industries, construction labour and gangs of migrants picked up at daily meeting points. He extended his gaze to their way of life in the slum colonies that sprang up around Bhilai where these men and women, adults and minors, found shelter, deprived from steady, regular employ and forced to make do with paltry and erratic pay. While painstakingly attesting to the huge diversity of employment modalities outside the Bhilai estate, Parry was also forced to register the dilution of formal employment over time, which changed the shape of the workforce within the plant. As production capacity steadily went up, management had started to replace part of its original core of permanent operators by much cheaper contract labour shorn of prerogatives that remained restricted to the earlier batches. In shopfloor-level management, the old-timers were tasked with supervision over the downgraded newcomers with whom they did not mingle socially, neither at work nor off work.

The broad canvass which Parry targeted enabled him to process the database collected with his collaborator in a masterly narrative, intertwined with sophisticated and nuanced analysis, taking on board also what other scholars and activists of labour had documented for the period covered. The timeline of reporting amounts to over sixty years, roughly from the mid-1950s onwards until the final site visits were made in 2014. The lengthy and comprehensive coverage explains why the study has resulted in a hefty volume of 700 very readable pages. The main thesis put forward is that although India's classes of labour fall into many grades and clusters which are spread over a wide range of variegated conditions and behaviours, this complexity should be essentialised as a dichotomy. It is the contradiction between those fortunate enough to have qualified for naukri (service jobs) and those toiling in kam (labouring chores). The binary follows from the distinction made between formal and informal employment. My review aims to critically address the dualistic model that Parry has proposed, and to expound upon it as too simplified.

I do indeed acknowledge that the working class on which Parry has focused a major part of his research constitutes a labour salariat, enjoying conditions of work and life which sets them apart from the multitudes outside the privileged enclave depicted as a citadel. The salaried beneficiaries elevated to decent and dignified employment and livelihood naturally want to see their gains consolidated and are anxious to guard against intrusion from outside the gates, afraid that sharing the precious spoils of étatist benevolence would inevitably end in the loss of their endowment. Teaming up in collective action, the steel plant's workforce in permanent and protected employment was able to achieve these objectives.

This strategy of promoting the interests of public sector labour was highly effective in that it produced very tangible gains - for BSP employees. What it did not do was provide other fragments of labour with sufficient leverage to ratchet up their wages. The result was the creation of an increasingly privileged labour elite, and an increasingly wide gulf between them and the rest of 'the working class' (p. 279).

Keeping watch over the interests of its members, the Congress trade union - recognised as representative and considered "reasonable" by the management - has contributed to the 
maintenance of industrial peace for which the Bhilai undertaking is well-known. Even while many attempts have been made to mobilise the proletarian masses who are refused access to the citadel of labour in the public economy, this valiant effort to bring about bargaining power where it is missing usually tends to get either blocked or sabotaged by both capital and government. The elimination of the union set up for contract workers in Bhilai's industrial estate and the assassination of its founder and leader Niyogi, a death he himself dramatically foretold, was a test case which Parry discusses from beginning to end.

Getting organised or not underscores the contradiction that exists between the aristocracy mobilised in togetherness while the working masses on the opposite pole of bifurcation remain embroiled in fragmentation. They fail to establish a common front and fight in orchestrated resistance against the dictates of employers and their agents. There are a few exceptions such as the Self-Employed Women's Association (SEWA), which started in Ahmedabad half a century ago to organise female street and home-based workers throughout the country. With impressive vigour, more than a million members all over the country have been unionised, but SEWA's agenda mainly addresses the state, by and large avoiding direct confrontation with capital and its owners (Breman, 2020b). Conceding more implicitly than explicitly that India's workforce is subjected to the vagaries of predatory capitalism, Parry is wont to discuss exploitation as a relationship which prevails between the two classes of labour he has identified. Before stating my difference in opinion, I first have to point out his conceptualisation of class. Having posited that the contestation between labour and capital gets muted in Bhilai's public sector of employment, Parry opts for a definition of social class, expounding as Max Weber did on the distinct life chances and lifestyles discerned at the convoluted sites of his research. Nehru and his policy-makers tried to rein in the unbounded ploys of capitalism (as Bismarck had endeavoured to do in industrialising Germany). To suggest that this government intervention to provide piecemeal a modicum of legal protection and social security created "classes of labour" but in doing so reduced them to a duality, is in my view an overstatement which does not do justice to the diversified nature of waged work.

While the Marxist concept of class articulates the proletarianised engagement in the labour process, a broader definition of social class focuses on another feature as well - the mode of existence or life standard which splits up the workforce into multiple formations. Taking issue with Henry Bernstein's (2007: 6-7) phrasing of "classes of labour" as all those "who depend - directly or indirectly - on the sale of their labour power for their own daily reproduction" as unduly narrow, Parry zoomed in on the diversified nature of daily reproduction by investigating the differentiated livelihoods of the working class under his lens. During his multi-sited fieldwork, he investigated how their contrasting modes of existence are structured and passed on between generations. I am in agreement with Parry on the need to add, next to their labouring modality, the life standard dimension of the households under scrutiny as pivotal for highlighting the proletarian predicament and its changing gestalt over time. However, the debate on "classes of labour" is being waged far beyond the cleavage between the regimes of formality and informality. A much wider scope has been spelled out from various corners over the last decades (see Barbalet, 1982; Murphy, 1984 and Vester, 2003). Although of immediate relevance for our problematic, for the sake of brevity the much wider setting has to remain unexplored in this review essay.

My dissenting opinion with Parry is based on the anthropological fieldwork I have carried out in Gujarat, where soon after independence the large workforce engaged in the privatised textile industry dating back to the late colonial era was downsized by leaps and bounds (Breman, 2004). In Ahmedabad, reputed to be the Manchester of India, the mercantile capitalists who owned and operated fifty composite enterprises decided not to invest in new technology and to cut down on labour costs. The shift from mill production to flexible hire-and-fire in small-scale workshops, 
mainly located in the booming city of Surat, took shape in a process of informalisation suggesting that casual and irregular modes of employment would not only stimulate GDP growth but also benefit the labouring poor. This switch was speeded up towards the end of the twentieth century by the onset of neo-liberalism in all branches of economic activity. Globalised capitalism, ferociously pushed through from the commanding heights, freed market forces from being held in check by government control. The dictate went together with a drastic dwindling in size of the public sector, as well as the dismantling of regulations and non-implementation of existing labour legislation.

When I emphasise how labour is exploited by capital instead of finding succour in stateprovided security and protection, it is on the basis of my empirical findings in Gujarat and not because I am driven by political expediency. Instead of being motivated by a preconceived ideological parti-pris, as Parry suggests (p. 55), I came to reject the labour aristocracy thesis when the industrial workforce in Ahmedabad lost its secure and protected position during the last decades of the twentieth century. Deprived overnight of the statutory labour laws, these mill operators were ruthlessly sent back to the realm of informality. The closure of such corporate textile enterprises elsewhere as well (Mumbai, Kanpur, Coimbatore) seems to make Parry's argument that regular employees of large-scale industries outside the public sector managed to find and retain a safe haven in the citadel implausible.

The often-repeated evidence of intra-class exploitation resorted to by a top segment of the proletariat is less telling than Parry claims. Such abusive appropriation of labour value is also widely practised between and within ranks of the unprivileged workforce. This is exemplified by the rich gains that jobbers make when they contract work gangs of male sugarcane harvesters and brickmakers, who in their turn do not shy away from forcing wives and children to join them in their abysmal and heavily underpaid toil. Rather than implying that such behaviour demarcates the divisive interests among the working classes, of pivotal significance are the livelihood strategies underlying them. In contrast to the labouring poor, prone to exploit their kindred as well as themselves to cope with bare survival and avoid further sinking down, those higher placed in the echelons of labour do so to move up in the class hierarchy, aspiring to move out of the proletariat altogether. Falling apart in upward or downward mobility, these opposite routes culminate in accumulation versus dispossession - on the higher end striving for embourgeoisement as against warding off destitution at the lower end. Large contingents of waged labourers can be found hovering somewhere between these adverse poles of engagement. My objective for bringing up this multi-level differentiation is to argue that labour is not split up in a two-class dichotomy but spreads out over a wider range of employment-cum-livelihood modalities.

In order to discuss my dissenting premise more elaborately, I need to foreground a second central thesis Parry has put forward. According to him class has overtaken caste (as well as other primordial loyalties) in the structuring of social identity. Such a reconfiguration of consciousness though more as a class in itself than for itself - is also in my assessment amply and persuasively demonstrated for the elite which dominates habitation in the citadel. For sure, features of caste cohesiveness endure in rules of endogamy and patriarchy as well as in avoiding social (not sexual) interaction with a most denigrated section "beyond the pale". Nevertheless, "as an encompassing ideological framework the overall trend has been a weakening of its grip" (p. 23). But where are the walls of the citadel erected? Having been informed that Bhilai's plant and township are its prototypical heartland, we subsequently learn that instead of fixing its gateposts around public sector industries, the fault line is drawn "between regular employees in large organised sector units on which the law has some hold and workers without any real protection from it" (p. 48). The dichotomy which appeared so pertinent loses rigour when the lens is turned to the workforce in 
private industries, ending with the conclusion that:

The gap between BSP workers at the top and informal sector labour at the bottom is a gulf, but within the private sector labour force there is another crucial divide that distinguishes regular workers in the larger factories from all the rest. The former share more in common with the aristocracy of labour than with the 'labour class'; the latter more with the 'labour class' than with the regular BSP workforce (p. 355).

Are we in other words talking about a sliding scale? No, because inside versus outside the citadel happens to coincide with the gap in employment and livelihood that separates naukri from kam, coinciding with the division between organised and unorganised sector labour (p. 74). This argument allows Parry to include the workforce engaged on a regular basis in Bhilai, although highly differentiated in their terms and conditions of employment, as being part and parcel of his citadel.

No doubt, also for people at the bottom of the pile class structuration has intensified. This is substantiated in a chapter on caste and class in slum neighbourhoods around the Bhilai enclave which have become the domicile of the down and out. New forms of class distinction have arisen in these bastis, prompting residents to identify and associate more with people who share their own class position than with those of their own caste. In my own investigations I have commented on this finding as evidence of the inroads that capitalism has made in the milieu of impoverishment. Workers are also consumers and in that habitus are subjected to changing trends in life chances as well as fashions in lifestyles. I have argued that investment in costly rites de passage or ritual events should be seen as an attempt by caste-class underdogs to qualify for access to mainstream society (Breman, 2019/2020a: 249-50). Consumerism appears to strengthen classness but the workforce in the informal economy, bereft from collective action, fails to express class-based solidarity. Forced to roam around in the labour market for casual and irregular engagement, this huge reserve army is left with no other option than to articulate their caste ties or other primordial affinities.

In order to make sense of the class-caste complexity found in the ranks of waged labour and livelihood, I need to further spell out the distinction already made between upward and downward mobility. In contrast to my appraisal which starts from down below, Parry has commented on these trajectories from the vantage point of the citadel. Summing up the gap which separates this elite from proletarian existence, his conclusion is that these BSP employees are unequivocally middle class with their excellent monetary wage - in the family of public sector workers among the highest in the country - topped up by perks and benefits (p. 223). Earlier on he has specified the significance of their hidden earnings gained in moonlighting. "Side businesses" for which they find ample time and opportunity - such as lending money at usurious rates of interest, renting out vehicles or real estate, setting up micro-enterprises in which workers are exploited - attest to their endeavour to accumulate and move up in the class hierarchy.

From 'labour class' people they see themselves as entirely different - as they are in terms of lifestyles and consumption, their characteristic values and attitudes, and their orientation to time. While many of their children are likely to continue their upward trajectory, a great many will fall short of their fathers. Much depends on the generation to which he belonged and on where they were raised - in the Township or a housing colony, or in a 'labour class' basti (p. 223).

All this adds up to a long and steep axis of graded inequality, which in my perception assumes the character of a caste-class nexus. In or close to the citadel, working-class behaviour dominates and is expressed in regulated and/or regular employment in large-scale enterprises. In the nether echelons, unable to organise in collective action, caste identity or similar bonds of first-order 
belonging such as tribe, creed, ethnicity revealed in monolingual proficiency is bound to prevail. Striving for decent work and an enjoyable standard of living is further complicated and compounded by upward or downward mobility along the length of the axis. Parry discusses these divergent pathways first and foremost from the perspective of the labour aristocracy. However, both accumulation and dispossession are also found among the proletarian segments which he has clubbed together as constituting the "labouring class". Given the low wages in all branches of the informal economy, made more cumbersome by their irregular and unreliable pay, it will come as no surprise that aspirations for decent working conditions and a modicum of dignified life often remain discontented. The yield of simple tools, a tiny plot of arable land, a few head of cattle, a hand-pulled cart, a booth or some other durable assets may enable the owner to find bare wherewithal but not much more than that. It is the street-level scenery that Keith Hart (1973) has described in his seminal essay on urban income opportunities not put on official record which started the debate on the informality-formality divide. Saving up enough to climb up the ladder and leave the labouring class behind is not totally out of the question but does not frequently happen. To boost productivity and profits the operators of petty means of production would need credit, which they cannot get easily and at an affordable rate. To unleash the spirit of entrepreneurship in the milieu of the labouring poor, Hernando de Soto glorified microfinance instead of clamouring for enforced labour rights and the creation of jobs. It made him an ardent campaigner for the deployment of capitalism among the down and out (Soto, 1989, 2000).

Parry has opted for discussing dispossession also from the window of elite labour and asserts that...

... suicide is disproportionally concentrated in its aristocracy of labour. It is in households that currently depend on, or previously enjoyed, secure and remunerative public sector jobs that the propensity to suicide is greatest. Their vulnerability pre-eminently has to do with the difficulty of living up to the demands and meeting the expectations that membership in this upwardly mobile stratum imposes, and with the threat of dropping out into the ranks of the 'labour class' (p. 578).

Unnoticed by him remains the final and extremely dismal end of dispossession which follows in the process of proletarianisation from loss of control over one's own labour power and that of other members of the household. It is a form of immiseration which denies the freedom to decide when, where and how to seek waged work. I have addressed such slaving for livelihood, locked up in debt, as neo-bondage which implies selling off labour power in advance for less than the market rate and forced to wait for back pay until dismissal (Breman, 1996, 2007, 2013, 2016, 2019, 2020a). Parry quite rightly points out that farmer suicides, due to rural immiseration and indebtedness attributed to the vagaries of commercialised agriculture, are considered to have grown sky high, while there is hardly any information about the frequency of self-inflected death for the rural landless. I could not agree more with this criticism on the under-reporting class-wise of premature death, but am reluctant to accept Parry's suggestion that it is possibly higher in urban pockets. This is because rather than locale - urban or rural - I found that self-killing seems to be triggered by poverty boiling over in destitution. Among the labouring classes on which my fieldwork has focused, adversity which could not be overcome nor properly handled is of critical significance. This includes, for example, lasting and debilitating illness unrelieved by proper medication, incomeless old age, inability to get daughters married for lack of cash and credit, or inability to finance other wants which in the drive to mindless consumerism have become needs. In my experience mortality and its causes among the down-and-out classes often fail to become officially registered. 
The upshot of my argumentation confirms that Parry's "labour class" is indeed fractured. But the overwhelming majority of India's workforce - reckoned to include over 90 per cent of its total - is neither assembled in homogeneity nor is it falling apart in fragments which somehow remain fused in amalgamated heterogeneity. Outside the citadel the masses engaged in waged work are split up in demarcated zones. This vast landscape should not be imagined as an uninterrupted and levelled plain but as a slope broken up by well-delineated stepping stones which turn out to be stumbling blocks difficult to climb over. Nuanced throughout in his treatise, Parry appears to have anticipated the vista I am painting. He duly concedes that in the flat landscape of labour beyond the citadel multiple thresholds rise up. But in acknowledging this he pre-empts my proposition of walled demarcation: "Though the labour market is certainly segmented, the boundaries between segments are generally permeable, and there is a good deal of mobility across them" (p. 52). I do accept the nomenclature of a citadel for the classes of labour found in the Bhilai enclave. However, I beg to disagree strongly with the spectrum of infinite porousness outside its gates, and underscore instead the existence of solid rather than fluid boundaries between (1) regular versus casual employment together with their different wage payment modalities, as well as (2) regression into dispossession from poverty to pauperism. The first distinction pertains to differentiated spells of work and their consequences; the second one relates to separated grades of precarity and the resulting ability or inability to fully participate in waged work.

Which are the "classes of labour" distinct from each other in their modes of employment as well as in ways of life? Alessandra Mezzadri and Lulu Fan (2018) have argued that this is a useful analytical as well as heuristic tool to map labour relations and working life profiles worldwide. Operationalised in terms of caste, creed, ethnicity, gender, age and spatial derivation, all these categories are indicative of lower to higher degrees of marginality and vulnerability. Starting from a different angle, I am prone to fall back on my fieldwork-based classification dating back to my first publication on the informality regime: the labour elite, the petit bourgeoisie, the sub-proletariat and the paupers (Breman, 1994: 28). ${ }^{2}$ No doubt, it was a fuzzy and premature attempt to figure out complex class boundaries on the basis of a still inadequate body of an empirical round of investigations, until then mainly if not only conducted in urban metropoles of the Global South. I readily admit the need to reconsider my initial taxonomy on where and how to draw the lines of social class configuration in the realm of informality.

Why classes, Parry asks in a follow-up question. I am still inclined to subscribe to a fourfold division. It is now differently labelled for the massive middle range but not for the polar ends that is, at the elitist top end and at the residual bottom of the class hierarchy. In between are placed the somewhat skilled and not fully dispossessed own-account workers who, together with labourers hired in steady employ and pay, even though remote by far from the privileged treatment the salariat enjoys within the citadel, tend to lead a relatively stable life. Their income stretches over a longer period and allows them to spend it in accordant rhythm with the wage received. Moreover, this show of regularity, if not afflicted by failing health or addiction to drink or drugs, enables them either to borrow or to delay payment of whatever they want or are obliged to settle within their modest means. With such make-do behaviour, provided it remains spared from misfortune, they demonstrate their greater reliability, credibility and higher social status. The same holds true for self-employed workers who operate means of production (a booth or stall, some tools, a vehicle), which enables them to secure their meagre livelihood. This class also is fortunate enough to continue living in conjugal togetherness. The labourers dependent on casual employ, hired and

${ }^{2}$ This material was first published in 1976 as a series of articles in Economic and Political Weekly, and was then incorporated in my 2013 book, At Work in the Informal Economy of India. 
fired, occasionally have to scratch around for whatever chores come their way; they constitute a reserve army. Shorter or longer bouts of unemployment, and their consequences for gathering the cost of reproduction, have remained much understated in analysing the informal economy. In these more precarious households, members of employable age need to search wide and far for work. It forces them to hive off in multi-locationality which may last for a few weeks, a season, a couple of years or an entire working life. Irregularity instead of regularity of engagement in the labour process culminates in uneven life chances and lifestyles. Instead of detailing this for the rift between poverty and ultra-precarity, I refer to the study in which I have elaborated on the residual segment sunk in pauperised existence (Breman, 2016). I am aware that the class configuration which is my analysis of the frame of informality remains open to question. But irrespective of the particular phrasing, the character of employment in combination with greater or lesser shades of vulnerability implies the existence of multiple classes of labour. To conclude, and as Parry agreeably affirms, classness "is always a matter of degree and is never complete. The tighter their structuration, however, the more sharply they emerge as identifiable groups, though their boundaries can never 'be drawn like lines on a map"' (p. 46).

Parry's fieldwork rounds were over by 2014 and this is also where his analysis came to a halt. We remain uninformed about the changing shape and fate of the labouring classes later on. Though Parry insists that Bhilai's citadel has remained by and large intact, this is most certainly not the case elsewhere in the country. I find it difficult to resist the temptation to summarily consider the drastic turnaround in India's political and policy scenario in the same year and its relevance in retrospect for the themes on which his book has focused. My beginning note is that economic liberalisation has gone on unabated, resulting in a major contraction of much that was supposed to be shielded in the public sector, downsizing outlay on people's health care, education and housing in particular. The infrastructural make-up of the state required the continued accommodation of a sizable workforce in public transport, communication and sanitation, although private enterprise made heavy inroads in these service sectors. Many corporations, agencies and undertakings, when not completely eliminated, were transmogrified in so-called public-private partnership. It meant that while input was financed with funding from the public treasury, the netted output was looted away by owners and managers of mercantile capital. For all intents and purposes this neo-liberal interference has shrunk the public sector to little more than personnel of the state: a multi-level and multi-functional bureaucracy and judiciary fortified by a much-increased strong arm of military, police and a rapidly growing number of officials charged with the build-up of a highly authoritarian surveillance state. Prime Minister Narendra Modi has entrusted its architecture to Minister of Home Affairs Amit Shah, his close associate from Gujarat and sinister long-time schemer of Nacht und Nebel (night and fog) operations to get rid of what are viciously stigmatised as "enemies of the nation and its state".

Redemption of poverty, pledged time and again during Congress governance to spread welfare in the Gandhian way to the least and the last, never materialised. The turning tide of politics stemmed not only from the disillusionment of the down-and-out with their exclusion but also expressed the wrath of the better-off classes for even the lip service paid to the idea of having to share their prerogatives with all those who, in their parochial mindset, do not deserve to be treated as equals. The current clique of powermongers, which has steered the Hindutva juggernaut to hegemony from its home base in Gujarat, has mobilised the electorate by appealing to their primordial loyalties. The political agenda has a high ideological fervour and revolves around creed and caste. Directed from the top, the party dictates reach down to the grassroots and are executed by a dedicated cadre operating through front organisations. This ideologically loaded apparatus is backed up off and on by vigilantism to expose opposition and tackle hostile forces. Not all 
inhabitants of the country are considered to be worthy to join the movement's national mission. Beyond the pale of inclusion remain the impure, who sully with their presence the flag hoisted above the sacred soil of Hinduism. The proclamation of the main religious minority as the "enemy in our midst" calls for the seclusion of Muslims from mainstream society, an apartheid policy which has driven them to ghettoisation in city, town and village. However, Hindu communities considered inferior and incapable of lifting themselves up out of impoverishment to self-reliance in work and life are also ordained as unfit to take part in the majoritarian caucus.

On Republic Day, 26 January 2019, Modi expressed his concern over what he called a population explosion. His speech equated acceptance of the small family norm with patriotism. Bereft from means of production other than their raw labour power and evidently unwilling to search for employment sufficient for survival, these wayward people are considered to lack the mandatory stamina for self-reliance. Spokesmen of the Bharatiya Janata Party (BJP) have proposed a population control bill with punitive sanctions for anti-social segments - Dalits, Adivasis and Muslims mainly - which fall short of the target set for family planning: These improvident and undisciplined households should not be allowed to cast their vote in elections, be exempted from the Public Distribution System and deprived from all state-provided relief; this meagre safety net needs to remain restricted to "the deserving poor" who in their disciplined ethos of self-help duly qualify for admission to the ranks of citizenship. While the initiative has found widespread parliamentary endorsement - even by Congress which has a dismal reputation on this subject since the dark history of enforced sterilisation during Emergency in 1975 critical voices have argued that such legislation is prompted by Modi's failure to stem the rapidly shrinking GDP rate and generate the millions of jobs he promised in the campaign which led to his installation as Prime Minister in 2014. The four labour codes (on wages; on occupational safety, health and working conditions; on social security; and on industrial relations), recently driven through by BJP's majoritarian rule in parliament "to generate employment and to facilitate ease of doing business", have once again sacrificed the welfare and wellbeing of the workforce at large. The dictated code aims not to formalise but to informalise labour in an attempt to pre-empt all class-based action.

India's state and society as envisioned in and drummed up by Hindutva's politics has sharpened her ingrained axis of inequality and inequity. The "pariah problem" of colonial days has lingered on to become emphasised in mindless subjection to capitalist exploitation. The sustained insistence on cheap and docile labour is made manifest in new forms of subalternity neatly ranked in hierarchical order. Only segments of the population deemed eligible for citizenship are bestowed with its rights (Breman, 2020c). In collusion with the globalised stakeholders of capitalism the agents of state power, conquered by its vainglorious politicians, vehemently oppose attempts made by labour activists to articulate social identity along class lines. All those found guilty of reinforcing such consciousness of solidarity based on collective action are excommunicated and risk undetermined spates of detention, accused of forsaking the nation's destiny under the trumped-up charge of sedition. India has not only been taken over by forces of fascism but this reborn Blut und Boden (blood and soil) regime also classifies and stigmatises substantial portions of the labouring masses at the bottom of the pile as "the non-deserving poor" who have to be excluded from citizenship. It is the return of social Darwinism which was practised in the course of the transformation from an agrarian-rural to an industrial-urban way of life in an earlier heartland of predatory capitalism. 


\section{References}

Barbalet, J.M. (1982) Social Closure in Class Analysis: A Critique of Parkin. Sociology, 14(4): 484-497.

Bernstein, H. (2007) Capital and Labour from Centre to Margins. Paper prepared for the "Living on the Margins" conference, Stellenbosch University, 26-28 March 2007. http://pdf.steerweb.org/ WFP\%20ESSAY/Bernstein dsi.pdf (accessed 17 June 2016).

Breman, J. (1994) Wage Hunters and Gatherers: Search for Work in the Urban and Rural Economy of South Gujarat. Delhi: Oxford University Press.

Breman, J. (1996) Footloose Labour: Working in India's Informal Economy. Cambridge, UK: Cambridge University Press.

Breman, J. (2004) The Making and Unmaking of an Industrial Working Class: Sliding Down the Labour Hierarchy in Ahmedabad. Oxford, UK: Oxford University Press.

Breman, J. (2007) The Poverty Regime in Village India: Half a Century of Work and Life at the Bottom of the Rural Economy in South Gujarat. New Delhi: Oxford University Press.

Breman, J. (2013) At Work in the Informal Economy of India; A Perspective from the Bottom Up. New Delhi: Oxford University Press.

Breman, J. (2016) On Pauperism in Present and Past. New Delhi: Oxford University Press.

Breman, J. (2019) Capitalism, Inequality and Labour in India. Cambridge, UK: Cambridge University Press.

Breman, J. (2020a) Capitalism, Inequality and Labour in India. South Asia edition. New Delhi: Cambridge University Press.

Breman, J. (2020b) The Bane of the Labouring Poor under Globalized Capitalism. In The Informal Economy Revisited. Examining the Past, Envisioning the Future, edited by M. Chen and F. Carré. London and New York: Routledge.

Breman, J. (2020c) The Pandemic in India and its Impact on Footloose Labour. Indian Journal of Labour Economics, 63(4): 901-919.

Hart, K. (1973) Informal Income Opportunities and Urban Employment in Ghana. In Tbird World Employment: Problems and Strategy, edited by R. Jolly, E. de Kadt, H. Singer and F. Wilson. Harmondsworth, UK: Penguin.

Mezzadri, A. and L. Fan (2018) Classes of Labour at the Margins of Global Commodity Chains in India and China. Development and Change, 49(4): 1034-1063.

Murphy, R. (1984) The Structure of Closure: A Critique and Development of the Theories of Weber, Collins and Parkin. The British Journal of Sociology, 35(4): 547-556.

Parkin, F. (1979) Marxism and Class Theory: A Bourgeois Critique. London: Tavistock.

Soto, H. de (1989) The Other Path: The Invisible Revolution in the Third World. New York: Harper and Row.

Soto, H. de (2000) The Mystery of Capital: Why Capitalism Triumphs in the West and Fails Everywhere Else. London: Bantam Press.

Vester, M. (2003) 'Class and Culture in Germany. Sociologia, Problemas e Práticas, 42(May): 25-64.

\section{BIOGRAPHICAL NOTE}

JAN BREMAN is Emeritus Professor at the University of Amsterdam and Honorary Fellow at the International Institute of Social History. [Emal: j.c.breman@uva.nl] 